\title{
RETURNS TO COMPUTER USE: \\ A SIMPLE TEST ON THE PRODUCTIVITY INTERPRETATION
}

\author{
Hessel Oosterbeek ${ }^{*}$
}

\section{$\underline{\text { Abstract }}$}

This paper finds that returns to computer use do not vary with the intensity of computer use. This is evidence against the productivity interpretation of these returns and supports the view that returns to computer use can be attributed to unobserved heterogeneity.

October 1996

* University of Amsterdam, Department of Economics, Roetersstraat 11, 1018 WB Amsterdam; and Tinbergen Institute. I gratefully acknowledge useful comments by Joop Hartog on an earlier draft of this paper. 


\section{$\underline{1 \text { Introduction }}$}

Two competing explanations are put forward for the recent trend of increased wage inequality in many western countries. One explanation focuses on the role of international trade (Wood 1994 for instance), the other concentrates on the importance of skill-biased technological change (e.g. Bound and Johnson 1992). In most cases the evidence presented to support one explanation or the other is rather indirect. An exception is Krueger's (1993) influential study on the earnings effects of computer use on-the-job. Employing different US data sources and estimation techniques, Krueger concludes that computer usage at the workplace increases earnings by 10 to 15 percent. DiNardo and Pischke (1996) report finding for Germany which are quite close to the US results (although they also present findings that question Krueger's interpretation; see below). ${ }^{1}$

In this paper we present evidence about the returns to computer use from the Netherlands. Our analysis has four features that distinguishes it from (most) other studies. Firstly, it contains the first set of results for the Netherlands. Secondly, the analysis is applied to a data set consisting of a cohort of individuals who all were 53 years old in 1993. Therefore, we can ignore any complications related to age or cohort effects. Thirdly, in addition to loglinear wage equations, we can estimate a fixed effect model because the data set also contains information about wages (but not about computer use) in 1983. Hence, assuming that no one used a computer in 1983, we can relate the wage change between 1983 and 1993 to the use of a computer. ${ }^{2}$ Finally, and - as will turn out - most important, the data set does not only provide information about whether or not the respondent uses a computer, but also about the intensity of computer use. If using a computer raises wages because it increases productivity, we would expect that the wage gain is higher, the more intensive the use of computers. This implication is tested in this paper.

The remainder of this paper is organized as follows. Section 2 describes the data set and the choice of variables. Section 3 presents and discusses the empirical results. Section 4 summarizes and concludes.

$\underline{2 \text { Data }}$

The data for the analyses in this paper are taken from a longitudinal survey of a birth cohort of individuals in the Netherlands. All respondents were at the age of twelve enrolled in the final year of

\footnotetext{
${ }^{1}$ Other recent studies on the returns to computer use include Bell (1996) and Entorf et al. (1995).

${ }^{2}$ Bell (1996) also estimates a fixed effect model using a similar assumption.
} 
primary education in 1952. They were approached for re-interviews in 1983 and 1993. In 1952 information was collected mainly about school performance, ability and social background. In 1983 and 1993, questionnaires were sent out to gather information relating to schooling career and labor market position. Detailed descriptions of the process of data collection are given in Hartog \& Pfann (1985) and Jonker (1995).

A question included in the survey of 1993 (but not in that of 1983) asks about the use of a computer on-the-job. More precisely the question runs: "How frequently do you use in your work a (personal) computer or computer terminal?" For their answer, the respondents could choose between five categories (with in parentheses the sample frequencies): every day (43.9\%), every week (7.9\%), a few times per month (4.3\%), almost never (9.6\%), and never (34.2\%). The information about computer use will be the main explanatory variable in the wage equations estimated in this paper. We constructed two different (sets of) variables measuring computer use. The first one is a dichotomous index, where the groups of daily, weekly, monthly and "almost never" users are merged into the category of computer users, while the persons who never use a computer at their work form the category of non-computer users. The other way to measure computer use, is to create five dummy variables corresponding to the five different intensities of computer use. The paper presents estimation results based on both metrics.

The dependent variable in the wage regressions is the logarithm of the net hourly wage rate in 1993. In different specifications we include the following variables as covariates: gender, years of education, IQ, nine occupation dummies, six industry dummies and three firm size dummies.

In addition to the wage equations, we also present results from a wage growth equation. The dependent variable is the difference between the logarithms of net hourly wage rates in 1993 and 1983. The only explanatory variable is the indicator of computer use. Assuming that none of the respondents used a computer in 1983, this can be interpreted as a fixed effect model. 


\section{$\underline{3 \text { Empirical findings }}$}

Table 1 presents estimation results for different specification of the wage equation when computer use is measured by the dichotomous indicator. From the first column to the final column more covariates are entered in the regression, causing a drop of the effect of computer use on wages. When no other covariates are included, using a computer increases wages by $34.1 \%$. This effect diminishes to $15.2 \%$ after including years of education, IQ, gender, industry dummies and firm size dummies. When also the occupation dummies are included, the effect still exceeds $10 \%$. We think it therefore save to conclude that our results are comparable to those presented by Krueger (1993) for the US and DiNardo and Pischke (1996) for Germany, indicating a return to computer use in the range of 10-15\%. Results from a fixed effect model corroborate this. Regressing the difference of log wages in 1993 and 1983 on the computer use index, gives an estimate of 0.096 with a standard error of $0.041 .^{3}$

The straightforward interpretation of this finding is that using a computer raises a worker's productivity. In their recent paper, DiNardo and Pischke (1996) express some skepticism regarding this interpretation. They find almost similar wage effects for using a pen, pencil or chair on-the-job as for using a computer. This does not necessarily invalidate the productivity interpretation but seems more in line with an interpretation in terms of unobserved heterogeneity. Workers who use a computer onthe-job possess attributes that would have made them more productive anyhow.

Here we examine the productivity interpretation with a simple test. It seems a rather natural implication that if using a computer on-the-job increases productivity, that this increase must be larger the more frequent the computer is used. Based on the productivity interpretation we would therefore expect that if computer use is not measured dichotomously, but with five dummies measuring different levels of frequency, we find the largest wage effects for the most frequent users. Table 2 presents our findings for wage equations that include this alternative specification of computer use as regressors. Quite contrary to the prediction based on the productivity interpretation, we find that the returns to computer use do not vary with the intensity of computer use. Whether a worker uses a computer on-thejob at a daily basis or very infrequently (almost never), does not matter for the wage effect of computer use. This finding is robust with respect to different specifications of the wage equation. ${ }^{4} \quad \mathrm{~T} \mathrm{~h}$ e results from the fixed effect model again support the findings from the loglinear wage equations. For

\footnotetext{
${ }^{3}$ This coefficient underestimates the true effect if some individuals using a computer in $1993 \mathrm{did}$ already use a computer in 1983.

${ }^{4}$ Using F-tests, we find for all six specifications that the restriction that the coefficients for different intensities of computer use are equal, can not be rejected.
} 
daily, weekly, monthly and "almost never" computer users, the respective coefficients in the wage growth equation are: 0.096 (standard error 0.035), 0.099 (0.075), 0.1835 (0.081) and 0.045 (0.064). These outcomes corroborate that returns to computer use do not increase monotonically with frequency of computer use.

A result reported by Krueger for the US which supports his interpretation of skill-biased technological change is the finding of a positive interaction effect between computer use and education. Workers with higher levels of education gain higher productivity effects from computer use than lower educated workers. For Germany, DiNardo and Pischke (1996) fail to find such a positive interaction. Instead they report a significantly negative (!) interaction term between schooling level and computer use. They interpret this as evidence against the skill-biased technological change explanation. If neither the contents of schooling nor the nature of computer use in the US and Germany are very different, one would expect interaction effects with equal signs. As a possible explanation for their result DiNardo and Pischke mention that the German wage structure is too highly regulated. But they argue against this explanation that if that were the case, they should also find much lower effects for computer use in Germany than in the US, whereas they find almost similar returns.

In the light of the mixed evidence on complementarily of computer use and schooling, it is interesting to consider the results on this issue for the Netherlands. We estimated specifications with interaction terms between schooling and computer use and between IQ and computer use. For both types of interaction we find that once schooling (respectively IQ) is included as a covariate, the interaction term has a coefficient not significantly different from zero. These findings are thus in between the positive interaction reported for the US and the negative interaction reported for Germany.

\section{$\underline{4 \text { Conclusion }}$}

This paper presents results about the returns to computer use in the Netherlands. If computer use is measured as a dichotomous indicator, we find results that are almost similar to the findings reported by Krueger (1993) for the US and by DiNardo and Pischke (1996) for Germany. Workers who use a computer on-the-job earn 10-20\% higher wages than workers who do not use a computer. This holds over a range of different specifications of the wage equation and is also corroborated by the results from a fixed effect model. We present evidence against the interpretation that the return to computer use is caused by skill-biased technological change. A straightforward implication of that interpretation is that workers who use a computer more frequently earn higher returns than less frequent users. Our results show that once a worker uses a computer on-the-job, the intensity of computer use does not 
matter. Merely having access to a computer is enough to earn a substantial wage premium. It therefore seems that the dichotomous indicator computer use, effectively splits the population into two different subgroups. This suggests that the return to computer use can be attributed to unobserved heterogeneity.

\section{$\underline{\text { References }}$}

Bell, B.D., 1996, Skill-biased technical change and wages: evidence from a longitudinal data set, Oxford: Nuffield College.

Bound, J., and G. Johnson, 1992, Changes in the structure of wages in the 1980s: an evaluation of alternative explanations, American Economic Review 82, 371-392.

DiNardo, J.E., and J.-S. Pischke, 1996, The returns to computer use revisited: have pencils changed the wage structure too?, NBER Working Paper Series \#5606.

Entorf, H., M. Gollac and F. Kramarz, 1995, New technologies, wages, and worker selection, INSEE Working Paper.

Hartog, J., and G.A. Pfann, 1985, Vervolgonderzoek Noordbrabantse zesdeklassers, Amsterdam: University of Amsterdam.

Jonker, N., 1995, Vervolgonderzoek Noord Brabantse zesdeklassers, Amsterdam: University of Amsterdam.

Krueger, A.B., 1993, How computers have changed the wage structure: evidence from microdata, 1984-1989, Quarterly Journal of Economics 108, 33-60

Wood, A., 1994, North-South trade, employment and inequality: changing fortunes in a skill-driven world, Oxford: Clarendon Press. 


\begin{tabular}{|c|c|c|c|c|c|c|}
\hline model & 1 & 2 & 3 & 4 & 5 & 6 \\
\hline $\begin{array}{l}\text { computer } \\
\text { use }\end{array}$ & $\begin{array}{l}0.3413 \\
(0.029) * * *\end{array}$ & $\begin{array}{l}0.3308 \\
(0.028)^{* * *}\end{array}$ & $\begin{array}{l}0.1872 \\
(0.029)^{* * *}\end{array}$ & $\begin{array}{l}0.1699 \\
(0.029)^{* * *}\end{array}$ & $\begin{array}{l}0.1519 \\
(0.030)^{* * *}\end{array}$ & $\begin{array}{l}0.1114 \\
(0.031)^{* * *}\end{array}$ \\
\hline covariates & none & gender & $\begin{array}{l}\text { gender, } \\
\text { education }\end{array}$ & $\begin{array}{l}\text { gender, } \\
\text { education, } \\
\text { IQ }\end{array}$ & $\begin{array}{l}\text { gender, } \\
\text { education, } \\
\text { IQ, indus- } \\
\text { try, firm } \\
\text { size }\end{array}$ & $\begin{array}{l}\text { gender, } \\
\text { education, } \\
\text { IQ, in- } \\
\text { dustry, } \\
\text { firm size, } \\
\text { occupation }\end{array}$ \\
\hline adj R.sq & 0.1293 & 0.1672 & 0.2818 & 0.2873 & 0.2908 & 0.3473 \\
\hline RSS & 168.1 & 161.3 & 134.6 & 133.1 & 131.3 & 119.3 \\
\hline
\end{tabular}




\begin{tabular}{|c|c|c|c|c|c|c|}
\hline model & 1 & 2 & 3 & 4 & 5 & 6 \\
\hline $\begin{array}{l}\text { computer } \\
\text { use daily }\end{array}$ & $\begin{array}{l}0.3404 \\
(0.031)^{* * *}\end{array}$ & $\begin{array}{l}0.3246 \\
(0.031)^{* * *}\end{array}$ & $\begin{array}{l}0.1973 \\
(0.031)^{* * *}\end{array}$ & $\begin{array}{l}0.1798 \\
(0.031)^{* * *}\end{array}$ & $\begin{array}{l}0.1592 \\
(0.032) * * *\end{array}$ & $\begin{array}{l}0.1239 \\
(0.033)^{* * *}\end{array}$ \\
\hline $\begin{array}{l}\text { computer } \\
\text { use weekly }\end{array}$ & $\begin{array}{l}0.3677 \\
(0.054)^{* * *}\end{array}$ & $\begin{array}{l}0.3577 \\
(0.053)^{* * *}\end{array}$ & $\begin{array}{l}0.1531 \\
(0.052) * * *\end{array}$ & $\begin{array}{l}0.1381 \\
(0.052)^{* * *}\end{array}$ & $\begin{array}{l}0.1189 \\
(0.053)^{* * *}\end{array}$ & $\begin{array}{l}0.0517 \\
(0.052) \\
\end{array}$ \\
\hline $\begin{array}{l}\text { computer } \\
\text { use monthly }\end{array}$ & $\begin{array}{l}0.3834 \\
(0.070) * * *\end{array}$ & $\begin{array}{l}0.3861 \\
(0.069) * * *\end{array}$ & $\begin{array}{l}0.1974 \\
(0.066) * * *\end{array}$ & $\begin{array}{l}0.1785 \\
(0.066)^{* * *}\end{array}$ & $\begin{array}{l}0.1755 \\
(0.066)^{* * *}\end{array}$ & $\begin{array}{l}0.1320 \\
(0.064)^{* *}\end{array}$ \\
\hline $\begin{array}{l}\text { computer } \\
\text { use almost } \\
\text { never }\end{array}$ & $\begin{array}{l}0.3048 \\
(0.050)^{* * *}\end{array}$ & $\begin{array}{l}0.3119 \\
(0.049)^{* * *}\end{array}$ & $\begin{array}{l}0.1544 \\
(0.048) * * *\end{array}$ & $\begin{array}{l}0.1382 \\
(0.048)^{* * *}\end{array}$ & $\begin{array}{l}0.1308 \\
(0.048)^{* * *}\end{array}$ & $\begin{array}{l}0.0918 \\
(0.047)^{* *}\end{array}$ \\
\hline $\begin{array}{l}\text { computer } \\
\text { use never }\end{array}$ & reference & reference & reference & reference & reference & reference \\
\hline covariates & none & gender & $\begin{array}{l}\text { gender, } \\
\text { education }\end{array}$ & $\begin{array}{l}\text { gender, } \\
\text { education, } \\
\text { IQ }\end{array}$ & $\begin{array}{l}\text { gender, } \\
\text { education, } \\
\text { IQ, indus- } \\
\text { try, firm } \\
\text { size }\end{array}$ & $\begin{array}{l}\text { gender, } \\
\text { education, } \\
\text { IQ, in- } \\
\text { dustry, } \\
\text { firm size, } \\
\text { occupation }\end{array}$ \\
\hline adj R.sq & 0.1277 & 0.1657 & 0.2807 & 0.2861 & 0.2893 & 0.3471 \\
\hline RSS & 161.6 & 154.4 & 132.9 & 131.8 & 130.0 & 118.4 \\
\hline
\end{tabular}

